\title{
Effects of the Partial Replacement of Soybean Meal by Insect or Algae Meal in Chicken Diets with Graded Amino Acid Supply on Parameters of Gut Microbiology and Dietary Protein Quality
}

\author{
Susanne Velten', Carmen Neumann'1, Jenny Schäfer², Frank Liebert ${ }^{1}$ \\ ${ }^{1}$ Division Animal Nutrition Physiology, Department of Animal Sciences, Georg-August-University of Goettingen, Goettingen, \\ Germany \\ ${ }^{2}$ Division Microbiology and Animal Hygiene, Department of Animal Sciences, Georg-August-University of Goettingen, \\ Goettingen, Germany \\ Email: flieber@gwdg.de
}

How to cite this paper: Velten, S., Neumann, C., Schäfer, J. and Liebert, F. (2018) Effects of the Partial Replacement of Soybean Meal by Insect or Algae Meal in Chicken Diets with Graded Amino Acid Supply on Parameters of Gut Microbiology and Dietary Protein Quality. Open Journal of Animal Sciences, 8, 259-279.

https://doi.org/10.4236/ojas.2018.83020

Received: May 12, 2018

Accepted: July 10, 2018

Published: July 13, 2018

Copyright $\odot 2018$ by authors and Scientific Research Publishing Inc. This work is licensed under the Creative Commons Attribution International License (CC BY 4.0).

http://creativecommons.org/licenses/by/4.0/ (c) (i) Open Access

\begin{abstract}
Insects or algae are considered future solutions to substitute imported feed proteins like soybean meal (SBM) in animal nutrition. The objective of this research, as part of the multidisciplinary project "Sustainability transitions", focused on replacing 50\% SBM by partly defatted larvae meal from black soldier flies (Hermetia illucens) or the blue-green algae Spirulina platensis in meat type chicken diets. The current study aimed to evaluate the effects on body composition, protein quality, apparent precaecal digestibility (apcD) and parameters of intestinal microbiota. In total, 288 one-day-old male growing chickens (Ross 308 ) from a commercial hatchery were randomly allotted to 48 pens ( 6 birds per pen) across five diets, which were fed at a free choice level. The control diet utilized SBM, wheat and corn as main ingredients, and experimental diets replaced $50 \%$ of SBM by the alternative proteins under study. Amino acid (AA) supplementation of the final diets was conducted both at a basic level (diets HM, SM; Lys and Met added equal to the control diet) and an extended level of AA fortification (diets $\mathrm{HM}+\mathrm{SM}+$; extended supplementation of Lys, Met, Thr, Arg). After finishing the growth study, 4 individual birds per diet were slaughtered for whole body analyses to derive nutrient utilization and dietary protein quality parameters. Additionally, pooled chyme samples from 16 birds per diet (control, HM and SM) were analyzed to assess apcD and microbial parameters. Diets HM and SM with a basic level of AA fortification led to significant depressions in nutrient deposition and dietary protein quality. However, $\mathrm{HM}+$ and $\mathrm{SM}+$ diets with an extended level of AA supplementation led to significantly improved responses; however these were
\end{abstract}


still generally not on par with the control diet. The HM+ diet provided superior $\mathrm{CP}$ deposition and dietary protein quality, as compared to the $\mathrm{SM}+$ diet, but equal to the control diet. Results of gut microbiology yielded no significant effects due to feeding the alternative protein sources under study.

\section{Keywords}

Growing Chickens, N Utilization Model, Body Analyses, Feed Protein Quality, Gut Microbiology, Precaecal Digestibility, Spirulina platensis, Hermetia illucens

\section{Introduction}

More than 1 billion people are already facing chronic hunger, yet the world population is expected to increase to 9 billion by 2050 [1]. The Food and Agriculture Organization of the United Nations [2] anticipates that food requirements will have to increase by between $70 \%$ and $100 \%$ to both alleviate existing hunger and feed the additional 2 billion people. At present, the increasing use of arable land for the production of bioenergy plants, rather than crop plants, is leading to a serious reduction in available area for food production worldwide. Similarly, livestock production in the western hemisphere is consuming $85 \%$ of the global soy supply to make concentrated animal feeds (including fish feed). Soy cultivation causes the deforestation of areas with high biological value [3]; it requires a rate of high water consumption [4] and pesticide and fertilizer application [5]; and the high usage of transgenic varieties [6] could cause significant environmental deterioration [3]. The three major global soy producers (Brazil, the USA and Argentina) cultivate about 90 million hectares, annually. The intensification of livestock production in recent decades has forced the use of grains in animal diets, and soybean meal (SBM) has become the main protein source in diet formulation for pigs and poultry in the EU. In total, 35\% of the world's crop production is allocated for animal feed to indirectly, and inefficiently, produce food for humans (meat, eggs and dairy products) [7]. According to Radermacher [8], it could be possible to feed the world's population with a vegetarian diet; however such a drastic change in food consumption patterns is unlikely in the near future. Therefore, for the time being monogastric livestock will continue to play a role in human nutrition.

The nutritive needs of monogastric species include high quality and high quantities of protein in the diet. From a nutritional point of view, in addition to stable quantity and quality of production, protein sources must have a high protein content, an adequate amino acid profile, a high digestibility, a good palatability and no antinutritional factors [9]. In consequence, more feed protein for nutrient transformation by livestock is required, while concurrently ensuring global human nutritional needs; therefore, it is important to find out whether alternative protein sources are a viable and sustainable way forward [10] [11]. 
As one prospective protein alternative, insects received increased attention in Europe [12] due to their high protein content and adequate amino acid composition, which is widely comparable to conventional animal proteins [13] [14] [15] [16]. Black soldier fly (Hermetia illucens) is one of the most promising species in terms of nutritional value of their larvae [17]. De Marco et al. [18] pointed out that Hermetia illucens larvae meal is an excellent source of protein and energy in diets for growing chickens. The growth rate of chickens was improved when Hermetia illucens meal was included as an ingredient of a complete broiler feed [19]. Nonetheless, only limited information is available in order to optimize the use of this insect meal in broiler diets [18] [20]. Presently, in Europe insect-based meals are not authorized to be included in poultry feeds [21]. Nonetheless, since the $1^{\text {st }}$ of July 2017, processed insect protein has been authorized for the use in aquaculture by Regulation [22] subject to the fulfillment of several important preconditions.

An additional alternative protein source is blue-green algae meal from Spirulina platensis also because of its high protein content and its abundance of vitamins, pigments and minerals [23] [24] [25]. Spirulina meal has been found to be suitable as a substitute for conventional ingredients in poultry nutrition and yielded no detrimental effects when included up to $15 \%$ in broiler feeds [26]. However, detailed investigations about the optimized application of Spirulina platensis in chicken diets remain scarce.

As part of the multidisciplinary project "Sustainability Transitions in food production: alternative protein sources in socio-technical perspective" the present study aimed to evaluate the potential of both Hermetia illucens larvae meal and Spirulina platensis meal as alternative feed proteins for the substitution of SBM in diets for meat type chickens. As a first part of our investigations, zoo-technical responses as well as physiological gut parameters due to 50\% replacement of SBM have already been reported [27]. The current study continues with results on nutrient deposition, evaluation of the dietary protein quality and parameters of gut microbiology.

\section{Material and Methods}

The growth study was conducted at the Division Animal Nutrition Physiology of Goettingen University and approved by the Ethics Committee of the Lower Saxony Federal Office for Consumer Protection and Food Safety (LAVES), Germany.

\subsection{Stock and Husbandry}

The experiment was divided in a starter (1-21d) and a grower period (22-34d). Under environmentally controlled conditions (temperature, monochromatic red light for 23 hours), 288 one-day-old male growing chickens (Ross-308 line; WIMEX Agrarprodukte, Hatchery Rosefeld Germany) were randomly allotted to 48 floor pens (6 birds/pen). Birds were bedded on wood shavings and had free 
access to feed and water. Growth data and feed consumption were recorded weekly.

\subsection{Alternative Protein Sources}

The Hermetia illucens larvae meal used in this study was gained from a commercial German producer (Hermetia Futtermittel GbR, Baruth/Mark, Germany). The black soldier fly larvae were raised on a plant-based substrate (rye flour, wheat bran) and collected after 20 days of fattening. After a period of 14 hours of drying at temperatures between $65^{\circ} \mathrm{C}$ and $70^{\circ} \mathrm{C}$, the larvae were partly defatted with a screw press (Type AP08, Reinartz). Finally, the processed larvae were milled to yield a meal to be used in the further manufacturing of homogenous mixed diets.

The microalgae meal from Spirulina platensis was a commercial sun-dried powder obtained from Myanmar and declared to be free of GMO, irradiation, pesticides, colorants, preservatives and additives. The microcystine content, analyzed by an external laboratory (TeLA GmbH, Geestland, Germany), remained below the detection limit. Velten et al. [27] reported comprehensive information regarding the nutrient composition of the alternative proteins.

\subsection{Diets and Feeding}

The experimental design in both of the age periods utilized five diets, a control diet $(\mathrm{n}=12)$ and four diets with 50\% SBM substitution $(\mathrm{n}=9)$. The starter/grower control diets were based on SBM (39/32\%) wheat (33/38\%) and corn $(16 / 19 \%)$ as the main ingredients (Table 1), both with a basic and an extended level of AA fortification. For the basic level, Lys and Met were supplemented equally to the levels in the control diet (diets HM and SM). The extended level of AA fortification (diets $\mathrm{HM}+$ and $\mathrm{SM}+$ ) aimed to improve the dietary AA balance according to the currently adopted ideal AA ratio (IAAR) as reported by Wecke and Liebert [28]. In consequence, both the Lys and Met supply was elevated and further crystalline AAs (L-Thr, L-Arg, L-Val) were supplemented (Table 1). Analyzed nutrient composition of the diets is summarized in Table 2.

The pelleted diets were manufactured at the facilities of the Division Animal Nutrition Physiology at the University of Goettingen and were fed at a free choice level.

\subsection{Recorded Parameters}

\subsubsection{Feed Analysis}

Diets were analyzed for DM, N, CF, EE and CA according to the standards of VDLUFA [30]. In-feed nitrogen analyses were carried out using the DUMAS-method (TruMac ${ }^{\circledR}$, Leco Instrument GmbH, Moenchengladbach) and $\mathrm{CP}$ was calculated from nitrogen by a factor of 6.25. Amino acids were analyzed by ion-exchange chromatography (Biochrom ${ }^{\circledR} 30$, Biochrom Ltd. Cambridge, England) following acid hydrolysis with and without an oxidation step for the 
Table 1. Ingredient composition of experimental diets ( $\mathrm{g} / \mathrm{kg}$ as feed).

\begin{tabular}{ccccccccccc}
\hline \multirow{2}{*}{ Ingredients/Diets } & \multicolumn{4}{c}{ Starter period (1 - 21 d) } & \multicolumn{5}{c}{ Grower period (22 - 34 d) } \\
\cline { 2 - 11 } & Control & HM & SM & HM+ & SM+ & Control & HM & SM & HM+ & SM+ \\
\hline Wheat & 328.8 & 362.8 & 381.5 & 358.3 & 377.9 & 375.8 & 405.8 & 419.1 & 402.6 & 416.8 \\
Corn & 164.4 & 181.4 & 190.7 & 179.2 & 189.0 & 187.9 & 202.9 & 209.6 & 201.3 & 208.4 \\
Soybean meal & 390.0 & 195.0 & 195.0 & 195.0 & 195.0 & 320.0 & 160.0 & 160.0 & 160.0 & 160.0 \\
Insect meal & - & 145.4 & - & 145.4 & - & - & 119.0 & - & 119.0 & - \\
Algae meal & - & - & 118.2 & - & 118.2 & - & - & 97.0 & - & 97.0 \\
Soybean oil & 78.5 & 78.5 & 78.5 & 78.5 & 78.5 & 78.5 & 78.5 & 78.5 & 78.5 & 78.5 \\
Premix & 10.0 & 10.0 & 10.0 & 10.0 & 10.0 & 10.0 & 10.0 & 10.0 & 10.0 & 10.0 \\
DCP 40 & 11.0 & 12.0 & 12.0 & 12.0 & 12.0 & 10.0 & 8.0 & 10.0 & 8.0 & 10.0 \\
CaCO & 11.0 & 9.9 & 9.1 & 9.9 & 9.1 & 9.0 & 8.0 & 8.0 & 8.0 & 8.0 \\
NaCl & 3.0 & 1.7 & 1.7 & 1.7 & 1.7 & 3.0 & 2.0 & 2.0 & 2.0 & 2.0 \\
Wheat starch & - & - & - & - & - & - & - & - & 3.0 & 3.0 \\
TiO 2 & - & - & - & - & - & 3.0 & 3.0 & 3.0 & - & - \\
L-Lys-HCl & 1.3 & 1.3 & 1.3 & 3.2 & 4.4 & 0.8 & 0.8 & 0.8 & 2.4 & 3.5 \\
DL-Met & 2.0 & 2.0 & 2.0 & 4.1 & 3.5 & 2.0 & 2.0 & 2.0 & 3.0 & 2.0 \\
L-Thr & - & - & - & 0.6 & - & - & - & - & 0.4 & - \\
L-Arg & - & - & - & 2.2 & 0.7 & - & - & - & 1.4 & 0.1 \\
L-Val & - & - & - & - & - & - & - & - & 0.5 & 0.2 \\
\hline
\end{tabular}

$\mathrm{HM}=$ Hermetia meal diet with basic AA supply; SM = Spirulina meal diet with basic AA supply; HM+ = Hermetia meal diet with extended AA supply; SM+ $=$ Spirulina meal diet with extended AA supply; ${ }^{1}$ Added per $\mathrm{kg}$ of final diet: $2.1 \mathrm{~g}$ calcium, $0.8 \mathrm{~g}$ sodium, 5,000 IU vitamin A, 1,000 IU vitamin D3, $30 \mathrm{mg}$ vitamin E, $2.6 \mathrm{mg}$ vitamin $\mathrm{B} 1,4.8 \mathrm{mg}$ vitamin $\mathrm{B} 2,3.2 \mathrm{mg}$ vitamin $\mathrm{B} 6,20 \mu \mathrm{g}$ vitamin $\mathrm{B} 12,3 \mathrm{mg}$ vitamin $\mathrm{K} 3,50 \mathrm{mg}$ nicotinic acid, $10 \mathrm{mg}$ calcium pantothenate, $0.9 \mathrm{mg}$ folic acid, $100 \mu \mathrm{g}$ biotin, $1000 \mathrm{mg}$ choline chloride, $50 \mathrm{mg}$ Fe as iron-II-sulfate, monohydrate, $15 \mathrm{mg}$ Cu as copper-II-sulfate, pentahydrate, $120 \mathrm{mg}$ $\mathrm{Mn}$ as manganese-II-oxide, $70 \mathrm{mg} \mathrm{Zn}$ as zinc oxide, $1.4 \mathrm{mg}$ I as calcium iodate, hexahydrate, $0.28 \mathrm{mg}$ Se as sodium selenite, $0.55 \mathrm{mg}$ Co as alkaline cobalt-II-carbonate, monohydrate and $100 \mathrm{mg}$ butylhydroxytoluol.

Table 2. Analyzed content of crude nutrients and selected AAs of experimental diets.

\begin{tabular}{|c|c|c|c|c|c|c|c|c|c|c|}
\hline \multirow{2}{*}{ Diets } & \multicolumn{5}{|c|}{ Starter period $(1-21 \mathrm{~d})$} & \multicolumn{5}{|c|}{ Grower period $(22-34 \mathrm{~d})$} \\
\hline & Control & HM & SM & $\mathrm{HM}+$ & $\mathrm{SM}+$ & Control & HM & SM & $\mathrm{HM}+$ & SM+ \\
\hline & \multicolumn{10}{|c|}{ Crude nutrients (g/kgDM) } \\
\hline Crude protein & 249.5 & 249.6 & 236.4 & 259.3 & 241.4 & 220.2 & 217.7 & 207.4 & 230.9 & 207.2 \\
\hline Ether extract & 111.6 & 124.3 & 115.7 & 131.1 & 116.6 & 112.8 & 110.7 & 117.2 & 131.4 & 118.4 \\
\hline Crude fiber & 45.2 & 49.4 & 33.4 & 47.1 & 31.1 & 40.4 & 41.1 & 28.5 & 41.7 & 30.4 \\
\hline Crude ash & 65.6 & 60.1 & 58.1 & 60.4 & 59.2 & 61.6 & 55.6 & 55.2 & 56.5 & 53.5 \\
\hline $\mathrm{N}$-free extract & 528.1 & 516.6 & 556.4 & 502.1 & 551.7 & 565 & 574.9 & 591.7 & 539.5 & 590.5 \\
\hline \multirow[t]{2}{*}{$\operatorname{AME}_{\mathrm{N}}(\mathrm{MJ} / \mathrm{kgDM})^{1}$} & 14.4 & 15.2 & 15.4 & 15.3 & 15.4 & 14.8 & 15.5 & 15.6 & 15.6 & 15.6 \\
\hline & \multicolumn{10}{|c|}{ Amino acids $(\mathrm{g} / \mathrm{kg} \text { as-fed })^{2}$} \\
\hline Lys & 12.55 & 12.20 & 10.24 & 13.66 & 12.68 & 10.53 & 10.24 & 8.64 & 11.48 & 10.73 \\
\hline Met & 4.99 & 4.96 & 5.13 & 7.01 & 6.60 & 4.63 & 4.68 & 4.82 & 5.60 & 5.31 \\
\hline Met+Cys & 8.43 & 8.06 & 8.12 & 10.10 & 9.58 & 7.87 & 7.57 & 7.62 & 8.49 & 8.10 \\
\hline Thr & 7.84 & 7.86 & 7.80 & 8.38 & 7.78 & 6.92 & 6.94 & 6.89 & 7.27 & 6.88 \\
\hline Arg & 14.25 & 11.95 & 13.03 & 14.09 & 13.65 & 12.4 & 10.52 & 11.41 & 11.88 & 11.49 \\
\hline Val & 9.34 & 10.43 & 9.85 & 10.40 & 9.83 & 8.31 & 9.21 & 8.73 & 9.68 & 8.92 \\
\hline
\end{tabular}

$\mathrm{HM}=$ Hermetia meal diet with basic AA supply; SM = Spirulina meal diet with basic AA supply; HM+ = Hermetia meal diet with extended AA supply; SM+ $=$ Spirulina meal diet with extended AA supply; ${ }^{1} \mathrm{~N}$ corrected apparent metabolizable energy, calculated according to WPSA [29]. ${ }^{2}$ Derived from analyzed AA content of the ingredients. 
quantification of sulphur containing AAs. Crude fat was extracted following HCl-hydrolysis.

\subsubsection{Whole Body Analysis and Nutrient Utilization Parameters}

For analyses of body composition, 4 individual birds per diet with approximately average BW per group were killed by $\mathrm{CO}_{2}$-inhalation after $24 \mathrm{~h}$ feed deprivation, and were then packed into air-tight plastic bags and kept frozen at $-20^{\circ} \mathrm{C}$ until further processing. The homogenization procedure of the birds started with autoclaving (4 hours at $110^{\circ} \mathrm{C}$, pressure about $1 \mathrm{bar}$ ). After final homogenization, about $500 \mathrm{~g}$ fresh matter was taken as a final sample for further nutrient analysis (DM, CA, and CP) according to the standards of VDLUFA [30].

The difference between the nutrient content at the end of the trial and of analyzed birds at the beginning (data from Pastor [31]) was calculated to yield nutrient deposition data. Energy deposition was calculated based on nutrient deposition making use of $23.7 \mathrm{~kJ} / \mathrm{g}$ body protein and $39.8 \mathrm{~kJ} / \mathrm{g}$ body fat [32].

Protein utilization and energy utilization were derived according to Equation (1) and (2):

$$
\begin{gathered}
\operatorname{PPV}(\%)=\left(\frac{\text { Protein deposition }(\mathrm{g})}{\text { Protein intake }(\mathrm{g})}\right) 100 \\
\text { Energy utilization }(\%)=\left(\frac{\text { Energy deposition }(\mathrm{MJ})}{\operatorname{Energy} \operatorname{intake}(\mathrm{MJ})}\right)
\end{gathered}
$$

whereby

PPV = Productive protein value.

Traditional measures of dietary protein utilization were applied according to the review of [33] and were significantly improved by a standardization procedure, as described in the next subsection.

\subsubsection{Standardized Protein Evaluation by "Goettingen Approach"}

Through the application of an exponential $\mathrm{N}$ utilization model [33]-[38], fundamentally created by Gebhardt [39], dietary protein quality was evaluated.

Equation (3) and Equation (4) summarize the fundamental aspects of the applied "Goettingen approach":

$$
\begin{gathered}
\mathrm{NR}=\mathrm{NR}_{\text {max }} \mathrm{T}\left(1-e^{-b * N I}\right) \\
\mathrm{ND}=\mathrm{NR}_{\text {max }} \mathrm{T}\left(1-e^{-b * N I}\right)-\mathrm{NMR}
\end{gathered}
$$

whereby

$$
\begin{aligned}
& \mathrm{NR}=\text { daily } \mathrm{N} \text { retention }(\mathrm{ND}+\mathrm{NMR})\left[\mathrm{mg} / \mathrm{BW}_{\mathrm{kg}}^{0.67}\right] ; \\
& \mathrm{ND}=\text { daily } \mathrm{N} \text { deposition or } \mathrm{N} \text {-balance }\left[\mathrm{mg} / \mathrm{BW}_{\mathrm{kg}}^{0.67}\right] ; \\
& \mathrm{NMR}=\text { daily } \mathrm{N} \text { maintenance requirement }\left[\mathrm{mg} / \mathrm{BW}_{\mathrm{kg}}^{0.67}\right] ; \\
& \mathrm{NR}_{\max } \mathrm{T}=\text { theoretical maximum for daily } \mathrm{N} \text { retention }\left[\mathrm{mg} / \mathrm{BW}_{\mathrm{kg}}^{0.67}\right] ; \\
& b=\text { model parameter for the slope of the function between } \mathrm{NI} \text { and } \mathrm{NR} \text {, de- } \\
& \text { pending on the dietary protein quality } \mathrm{NI}=\text { daily } \mathrm{N} \text { intake } \mathrm{NR}_{\max } \mathrm{T}\left[\mathrm{mg} / \mathrm{BW}_{\mathrm{kg}}^{0.67}\right] ;
\end{aligned}
$$


$e=$ basic number of natural logarithm [ln].

The genotype dependent model parameters for daily NMR (240 $\left.\mathrm{mg} / \mathrm{BW}_{\mathrm{kg}}^{0.67}\right)$ and $\mathrm{NR}_{\max } \mathrm{T}$ were taken from earlier experiments with fast growing chickens where the same genotype was under study [40]. However, according to the whole growth period under study, an averaged $\mathrm{NR}_{\max } \mathrm{T}\left(3840 \mathrm{mg} / \mathrm{BW}_{\mathrm{kg}}^{0.67}\right)$ for starter and grower chickens was applied. Following logarithmic transformation of Equation (3), model parameter " $b$ " provides a NI independent measure of dietary protein quality according to Equation (5):

$$
b=\frac{\left[\ln \mathrm{NR}_{\text {max }} \mathrm{T}-\ln \left(\mathrm{NR}_{\text {max }} \mathrm{T}-\mathrm{NR}\right)\right]}{\mathrm{NI}}
$$

For increased transparency, traditional parameters like productive protein value (PPV) and net protein utilization (NPU) were additionally applied as measures of the complex dietary protein quality by taking into account the processes involved in digestion and post-absorptive utilization (Equation 6 and Equation 7).

$$
\begin{aligned}
& \operatorname{PPV}(\%)=\frac{N D}{N I} \\
& \operatorname{NPU}(\%)=\frac{N R}{N I}
\end{aligned}
$$

However, these measures are not independent of the level of realized protein intake [41] [42] [43]. Consequently, a standardization of protein intake was conducted according to Thong and Liebert [42], which provided NPU data that are independent of NI [31] [42] [43] [44] [45].

Accordingly, standardized productive protein value $\left(\mathrm{PPV}_{\text {std }}\right)$ and standardized net protein utilization $\left(\mathrm{NPU}_{\text {std }}\right.$ ) were calculated (equation 8 and 9) for equal daily nitrogen intake $\left(\mathrm{NI}_{\text {std }}: 3000 \mathrm{mg} / \mathrm{BW}_{\mathrm{kg}}^{0.67} / \mathrm{d}\right)$ to ensure the comparability of derived PPV and NPU data:

$$
\begin{gathered}
\mathrm{PPV}_{\text {std }}=\mathrm{NR}_{\text {max }} \mathrm{T} \frac{\left(1-e^{-b * \mathrm{NIstd}}\right)-\mathrm{NMR}}{\mathrm{NI}_{\text {std }}} \\
\mathrm{NPU}_{\text {std }}=\mathrm{NR}_{\text {max }} \mathrm{T} \frac{\left(1-e^{-b * \mathrm{NIstd}}\right)}{\mathrm{NI}_{\text {std }}}
\end{gathered}
$$

Assessment of parameter " $b$ " according to Equation 5 is a prerequisite for application of this standardization procedure.

\subsubsection{Precaecal Digestibility of Protein and Amino Acids}

At the end of the grower period, 16 separate birds per diet were pooled to yield a sample size of 4 to measure apparent precaecal digestibility (apcD) for the 3 diets (control, HM and SM). Average BW chickens were selected and euthanized by $\mathrm{CO}_{2}$ inhalation. According to Kluth et al. [46], chyme samples were immediately collected from the last $2 / 3$ of the section between Meckel's diverticulum and 2 $\mathrm{cm}$ before the ileocaecal junction. Following freeze-drying, samples were ana- 
lyzed for DM, N, AA and $\mathrm{TiO}_{2}$ as the indigestible marker (0.3\% of the diet).

$\mathrm{TiO}_{2}$ in feed and digesta samples was determined by KJELDAHL-digestion (Büchi 430 Digestor) and a subsequent photometrical detection at $405 \mathrm{~nm}$ wavelength, following Brandt and Allam [47]. Analyses of N and AA in feed and digesta samples were conducted according to the standard procedures of VDLUFA [30] (see 2.4.1).

The calculation of apcD data (Equation 10) was according to Kluth and Rodehutscord [48]:

$$
\operatorname{apcD}=100-100 \frac{\left(\mathrm{TiO}_{2 \text { Diet }} * \mathrm{AA}_{\text {Digesta }}\right)}{\left(\mathrm{TiO}_{2 \text { Digesta }} * \mathrm{AA}_{\text {Diet }}\right)}
$$

whereby

$\mathrm{apcD}=$ apparent precaecal digestibility (\%);

$\mathrm{TiO}_{2 \text { Diet }}$ and $\mathrm{TiO}_{2 \text { Digesta }}=$ respective concentrations of $\mathrm{TiO}_{2}$ in the diet and digesta samples $(\mathrm{g} / \mathrm{kg})$;

$\mathrm{AA}_{\text {Diet }}$ and $\mathrm{AA}_{\text {Digesta }}=$ respective concentrations of the $\mathrm{AA}$ in the diet and digesta samples $(\mathrm{g} / \mathrm{kg})$.

\subsubsection{Microbiology}

Microbiological studies utilized the same birds as applied for assessing apcD (2.4.4). However, chyme samples were collected from the duodenum up to the first 1/3 of the section between Meckel's diverticulum and $2 \mathrm{~cm}$ before the ileocaecal junction. Samples were immediately prepared for further investigation of gut microbiology. In addition, the experimental diets (control, HM and SM) were subjected to the same anaylses to check their microbial status.

1) Cultivation of bacteria

Before cultivation, material samples were mixed within a sterile plastic bag (in a solution of buffered peptone water (Thermo Fisher Scientific Oxoid, Germany) using a paddle blender at the highest level for 3 min (Stomacher ${ }^{\circledR} 400$ Circulator, Seward, UK). Subsequently, the cell suspensions were diluted in a tenfold dilution series up to $10-8$. From the dilutions, each two agar plates were inoculated either by plating $0.25 \mathrm{ml}$, or in the case of the plate count technique, by mixing the nutrition media with $1 \mathrm{ml}$ of the corresponding suspension. For the detection and enumeration of different bacterial groups the following media were chosen:

PCA (plate-count agar, Carl Roth, Germany) for total colony forming units, VRBD-agar (violet red bile glucose agar; Thermo Fisher Scientific Oxoid, Germany) for Enterobacteriaceae (DIN ISO 21528-2:2009), OPSP-agar (perfringens agar, containing perfringens selective supplement $\mathrm{A}$ and $\mathrm{B}$; Thermo Fisher Scientific Oxoid, Germany) for Clostridium species, CATC (citrat-azid-tween carbonate-agar; Sifin, Germany) containing Tween 80, (Carl Roth) for enterococci, Brilliance TM E. coli/Coli form Selective Agar (Thermo Fisher Scientific Oxoid, Germany) for E. coli, deMAN, Rogosa and Sharpe Agar (Merck, Germany) for lactic acid bacteria (DIN 10109:2016-05). 
The presence of Salmonella and Campylobacter species was achieved by the inoculation of enriched broths and sub-cultivation on specific media according to EN ISO 6579:2002+A1:2007 and EN ISO 10272-1:2006. For the detection of Salmonella species the sample was diluted 1:10 in buffered peptone water and incubated for $24 \mathrm{~h}$ at $37^{\circ} \mathrm{C}$. Afterwards, samples were fractionated on three different selective agar plates (MSRV, modified semi-solid rappaport vassiliadis media, X.L.D. medium and Brilliance TM Salmonella; FirmaOxoid, Thermo Fisher Scientific). MSRV inoculated agar plates were further incubated at $42^{\circ} \mathrm{C}$ for 48 h. X.L.D. and Brilliance TM Salmonella agar inoculated plates were incubated at $37^{\circ} \mathrm{C}$ for $24 \mathrm{~h}$. To study the presence of Campylobacter, $1 \mathrm{~g}$ fresh material was added to $9 \mathrm{ml}$ of Bolton Broth containing bolt on broth selective supplement and lysed horse blood (Thermo Fisher Scientific, Oxoid). The samples were initially incubated at $37^{\circ} \mathrm{C}$ for 4-6 hours, followed by an incubation period of $48 \mathrm{~h}$ at $42^{\circ} \mathrm{C}$. Afterwards, CCDA agar plates were inoculated by plating 0.25 $\mathrm{ml}$ of the enrichment broth, followed by incubation at $42^{\circ} \mathrm{C}$ for $48 \mathrm{~h}$. With the exception of campylobacter detection media, all other nutritional media were incubated for $1-4$ days at $37^{\circ} \mathrm{C}$ under aerobic conditions. In case of campylobacter detection, incubation was conducted under microaerophilic conditions using Campygen bags (Thermo Fisher Scientific, Oxoid) in an anaerobic jar. Additionally, feed material was examined. According to DIN EN ISO 7218, colonies were counted on agar plates taking into account agar plates with 10-300 colonies. To confirm the detection of each bacterial group, five to ten of the colonies showing the specific appearances on the different agar plates were transferred to another agar plate containing sub-cultivation media (Columbia blood agar containing $70 \mathrm{ml}$ human blood per litre (Thermo Fisher Scientific, Oxoid, Germany). Strain assignment was proven using Gram staining, biochemical test, or $16 \mathrm{~S}$ rRNA gene analysis.

2) Microscopy of parasites

For the detection of parasites, the fast and slow flotation method was applied as described by Dryden et al. [49]. In total 3 - $5 \mathrm{~g}$ fresh sample was homogenized in a 10 fold dilution with flotation solution (saturated sodium-chloride solution, density of 1.2). In the case of fast flotation, the solution was filtered afterwards through a sieve into two $10 \mathrm{ml}$ glass tubes and centrifuged for $3 \mathrm{~min}$ at $300 \mathrm{~g}$. The slow flotation filtered solution was transferred into a $100 \mathrm{ml}$ tube and incubated for $30 \mathrm{~min}$ at room temperature. The surface layer of the solutions was pipetted onto glass slides and the examined for the occurrence of parasites or parasite eggs.

\subsection{Statistical Analysis}

Results are presented as means \pm standard deviation. Statistical analysis of the data is based on one-way ANOVA using the software package SPSS (IBM SPSS Statistics, Version 24.0) connected with the Tukey-test and the Games-Howell-test to identify significant differences between treatments $(p \leq 0.05)$. 


\section{Results}

\subsection{Body Nutrient Composition and Nutrient Deposition}

Body nutrient composition data of meat-type chickens at the end of the growth trial are summarized in Table 3. The highest CP content and the concurrent lowest ether extract (EE) content in body DM was found in control diet birds. A significant effect on CP content in DM was only observed between the control and $\mathrm{SM}+$ diet, but not between SM, HM, and HM+ diets, respectively. The SM+ diet yielded the lowest $\mathrm{CP}$ content in whole body DM. The same ranking, but in the reverse order was observed for EE in DM, with a significant effect between the $\mathrm{SM}+$ diet and the control group.

Calculation of the body energy content provided no significant difference between diets. However, there was a trend for higher energy contents in birds fed the SM+ diet and the lowest levels were in control birds.

Considering the nutrient deposition, overall the basic level of AA supplementation resulted in lower nutritional deposition values. The basic level of AA supplementation (diets HM and SM) yielded significantly lower CPD values as well as deposition of fat (EED), ash (CAD) and energy deposition (GED) were depressed. However, EED and CAD were similar to animals of the $\mathrm{HM}+$ and $\mathrm{SM}+$ diets and the control. On the other hand, the highest daily protein deposition (CPD) value was found for the AA balanced HM+ diet, but this was not significantly different from the control. Nonetheless, both EED and CAD were significantly enhanced in birds fed the diets with extended AA supply. The calculated results were similar; both $\mathrm{HM}+$ and $\mathrm{SM}+$ diets achieved GED data superior to that of the control birds $(p \leq 0.05)$.

\subsection{Protein Quality}

The $\mathrm{N}$ deposition data presented in Table 3 were further applied in the calculation of $\mathrm{N}$ utilization parameters (Table 4). Accordingly with the low variation of

Table 3. Body nutrition composition at the end of the 5 week trial and observed nutrient and energy deposition ${ }^{1}$.

\begin{tabular}{|c|c|c|c|c|c|c|c|c|c|c|}
\hline \multirow[t]{3}{*}{ Diet } & \multicolumn{4}{|c|}{ Nutrient content } & \multirow{3}{*}{$\begin{array}{c}\text { Energy } \\
(\mathrm{M}) / \mathrm{kg} \mathrm{DM}) \\
\mathrm{GE}\end{array}$} & \multirow[b]{3}{*}{$\mathrm{n}$} & \multirow{2}{*}{\multicolumn{3}{|c|}{$\begin{array}{c}\text { Nutrient deposition } \\
\text { (g/d) }\end{array}$}} & \multirow{3}{*}{$\begin{array}{c}\begin{array}{c}\text { Energy } \\
\text { deposition }\end{array} \\
(\mathrm{kJ} / \mathrm{d}) \\
\mathrm{GE}\end{array}$} \\
\hline & $(\%)$ & & (g/kg DM) & & & & & & & \\
\hline & $\mathrm{DM}$ & $\mathrm{CP}$ & $\mathrm{EE}$ & $\mathrm{CA}$ & & & $\mathrm{CP}$ & $\mathrm{EE}$ & $\mathrm{CA}$ & \\
\hline $\begin{array}{l}\text { Day old } \\
\text { chicken }\end{array}$ & $22.54 \pm 0.18$ & $687.9 \pm 12.1$ & $226.9 \pm 11.3$ & $85.2=$ & $25.33 \pm 0.17$ & & & & & \\
\hline Control & $29.91^{\mathrm{a}} \pm 1.71$ & $570.2^{\mathrm{b}} \pm 21.0$ & $354.0^{\mathrm{b}} \pm 24.2$ & $75.8^{\mathrm{ab}} \pm 4.4$ & $27.60 \pm 0.48$ & 12 & $11.05^{\mathrm{d}} \pm 0.58$ & $6.92^{c} \pm 0.36$ & $1.47^{c} \pm 0.08$ & $537^{c} \pm 28$ \\
\hline HM & $31.14^{\mathrm{ab}} \pm 0.76$ & $522.1^{\mathrm{ab}} \pm 24.1$ & $395.1^{\mathrm{ab}} \pm 26.3$ & $82.8^{\mathrm{b}} \pm 2.7$ & $28.10 \pm 0.48$ & 9 & $7.16^{\mathrm{b}} \pm 0.44$ & $5.51^{\mathrm{b}} \pm 0.33$ & $1.14^{\mathrm{b}} \pm 0.07$ & $389^{\mathrm{b}} \pm 24$ \\
\hline SM & $29.90^{\mathrm{a}} \pm 0.73$ & $536.3^{\mathrm{ab}} \pm 20.2$ & $379.1^{\mathrm{ab}} \pm 22.2$ & $84.5^{\mathrm{b}} \pm 2.4$ & $27.80 \pm 0.41$ & $8^{2}$ & $4.95^{\mathrm{a}} \pm 0.31$ & $3.58^{\mathrm{a}} \pm 0.22$ & $0.79^{\mathrm{a}} \pm 0.05$ & $260^{a} \pm 16$ \\
\hline $\mathrm{HM}+$ & $31.69^{\mathrm{ab}} \pm 1.36$ & $531.4^{\mathrm{ab}} \pm 27.7$ & $394.8^{\mathrm{ab}} \pm 34.8$ & $73.8^{\mathrm{ab}} \pm 7.4$ & $28.31 \pm 0.73$ & 9 & $11.64^{\mathrm{d}} \pm 0.58$ & $8.73^{\mathrm{d}} \pm 0.43$ & $1.62^{\mathrm{d}} \pm 0.08$ & $623^{d} \pm 31$ \\
\hline $\mathrm{SM}+$ & $32.92^{\mathrm{b}} \pm 1.13$ & $493.7^{\mathrm{a}} \pm 19.5$ & $433.1^{\mathrm{a}} \pm 20.9$ & $73.2^{\mathrm{a}} \pm 2.8$ & $28.95 \pm 0.38$ & 9 & $10.23^{c} \pm 0.60$ & $9.08^{\mathrm{d}} \pm 0.53$ & $1.52^{\mathrm{cd}} \pm 0.09$ & $604^{\mathrm{d}} \pm 35$ \\
\hline
\end{tabular}

$\mathrm{HM}=$ Hermetia meal diet with basic AA supply; SM = Spirulina meal diet with basic AA supply; HM+ = Hermetia meal diet with extended AA supply; SM+ $=$ Spirulina meal diet with extended $\mathrm{AA}$ supply; $\mathrm{CP}=$ crude protein; $\mathrm{EE}=$ ether extract; $\mathrm{CA}=$ crude ash; $\mathrm{GE}=$ gross energy; ${ }^{1} \mathrm{Mean} \pm$ standard derivation; ${ }^{2}$ one box excluded because of an outlier in feed conversion ratio, detected with SPSS boxplot-test $(p \leq 0.05)$; ${ }^{\text {a-d }}$ Means with different superscript letters within in the same columns are significantly different $(p \leq 0.05)$. 
Table 4. Diet dependent N-utilization parameters of growing meat type chickens based on observed protein deposition data (whole body $\mathrm{N}$ analyses) ${ }^{1}$.

\begin{tabular}{|c|c|c|c|c|c|}
\hline Diet & Control & HM & SM & $\mathrm{HM}+$ & SM+ \\
\hline $\mathrm{n}$ & 12 & 9 & $8^{2}$ & 9 & 9 \\
\hline Model parameter $\mathrm{b}^{*}\left(\times 10^{-6}\right)$ & $225^{\mathrm{c}} \pm 7$ & $162^{\mathrm{a}} \pm 15$ & $151^{\mathrm{a}} \pm 8$ & $228^{\mathrm{c}} \pm 7$ & $215^{\mathrm{b}} \pm 4$ \\
\hline Net protein utilization (NPU) (\%) & $63.0^{\mathrm{b}} \pm 1.8$ & $50.0^{\mathrm{a}} \pm 4.4$ & $46.6^{\mathrm{a}} \pm 2.4$ & $63.5^{\mathrm{b}} \pm 2.0$ & $61.4^{\mathrm{b}} \pm 1.4$ \\
\hline $\mathrm{NPU}_{\text {std } 3000}{ }^{* *}(\%)$ & $62.9^{c} \pm 1.3$ & $49.1^{\mathrm{a}} \pm 3.7$ & $46.7^{\mathrm{a}} \pm 2.1$ & $63.4^{\mathrm{c}} \pm 1.3$ & $60.9^{\mathrm{b}} \pm 0.9$ \\
\hline Protein utilization (PPV) (\%) & $55.1^{c} \pm 1.6$ & $40.9^{\mathrm{a}} \pm 3.8$ & $38.9^{\mathrm{a}} \pm 2.1$ & $55.6^{\mathrm{c}} \pm 1.7$ & $53.3^{\mathrm{b}} \pm 1.2$ \\
\hline $\mathrm{PPV}_{\text {std } 3000}{ }^{*}(\%)$ & $54.9^{\mathfrak{c}} \pm 1.3$ & $41.1^{\mathrm{a}} \pm 3.7$ & $38.7^{\mathrm{a}} \pm 2.1$ & $55.4^{\mathrm{c}} \pm 1.3$ & $52.9^{\mathrm{b}} \pm 0.9$ \\
\hline
\end{tabular}

$\mathrm{HM}=$ Hermetia meal diet with basic AA supply; $\mathrm{SM}=$ Spirulina meal diet with basic AA supply; HM+ = Hermetia meal diet with extended AA supply; SM+ = Spirulina meal diet with extended AA supply; ${ }^{1}$ Mean \pm standard derivation; ${ }^{2}$ one box excluded because of an outlier in feed conversion ratio, detected with SPSS boxplot-test $(p \leq 0.05) ;{ }^{\mathrm{a}-\mathrm{d}}$ Means with different superscript letters within lines are significantly different $(p \leq$ $0.05) ;{ }^{\star}$ Applied for NPU standardization based on: $\mathrm{NMR}=240 \mathrm{mg} / \mathrm{BW}_{\mathrm{kg}}^{0.67} / \mathrm{d} ; \mathrm{NR}_{\max } \mathrm{T}=3840 \mathrm{mg} / \mathrm{BW}_{\mathrm{kg}}^{0.67}$ $/ \mathrm{d} ;{ }^{* *}$ standardized daily $\mathrm{N}$ intake $=3000 \mathrm{mg} / \mathrm{BW}_{\mathrm{kg}}^{0.67}$.

$\mathrm{N}$ intake, the standardized parameters $\left(\mathrm{NPU}_{\text {std }}\right.$ resp. $\left.\mathrm{PPV}_{\text {std }}\right)$ were rather similar as compared to the traditional parameters (NPU resp. PPV). In spite of this, only the standardized parameters are used for further evaluations according to their complete independence on variation on N intake. Nonetheless, both NPU and PPV are presented due to the fact that PPV data are more comparable to traditional measures of protein utilization in the corresponding literature. However, further comparisons are focused on $\mathrm{NPU}_{\text {std }}$ data because of the more complex property of this protein quality parameter.

The basic level of AA supplementation, which was equal to the control diet, significantly impaired the feed protein quality of both alternative protein source diets. However, the dietary protein quality was significantly improved when the extended level of AA supplementation was applied (HM+ and SM+ diets). It has to be pointed out that only the HM+ diet achieved a protein quality equal to that of the control diet. The protein quality of the SM+ diet remained below the control diet $(p \leq 0.05)$.

\subsection{Apparent Precaecal Digestibility}

The results from assessing the apparent precaecal digestibility $(\mathrm{apcD})$ are summarized in Table 5. The measure was restricted to both the control diet and the diets with the basic level of AA supplementation (HM and SM). The reported data are not corrected for the non-protein nitrogen contained in the chitin fraction of the insect meal based diet HM. A significant difference for apcD of the crude protein fraction was observed between the control and SM diet. The HM diet yielded an intermediate result, without significant differences between the other diets. With a special focus on the apcD of selected AAs, a similar ranking between diets was observed for nearly all AAs except for methionine. In general, the results indicate that the diets under study differ markedly in parameters of apcD; however the results are based on a limited number of repetitions only and 
Table 5. Observed apparent precaecal digestibility of protein (\%) and selected AAs at the end of the trial ${ }^{1}$.

\begin{tabular}{cccc}
\hline Diet & Control & HM & SM \\
\hline $\mathrm{n}$ & $3^{2}$ & 4 & 4 \\
\hline Crude protein & $75.2^{\mathrm{b}} \pm 3.9$ & $67.9^{\mathrm{ab}} \pm 3.2$ & $60.9^{\mathrm{a}} \pm 6.2$ \\
Lysine & $82.3^{\mathrm{b}} \pm 6.6$ & $70.8^{\mathrm{ab}} \pm 3.0$ & $63.0^{\mathrm{a}} \pm 9.9$ \\
Methionine & $90.2^{\mathrm{a}} \pm 3.7$ & $85.0^{\mathrm{a}} \pm 2.2$ & $83.3^{\mathrm{a}} \pm 4.0$ \\
Methionine + Cystein & $82.6^{\mathrm{b}} \pm 4.3$ & $75.3^{\mathrm{ab}} \pm 2.6$ & $73.2^{\mathrm{a}} \pm 4.9$ \\
Threonine & $73.2^{\mathrm{b}} \pm 7.5$ & $63.2^{\mathrm{ab}} \pm 5.0$ & $56.1^{\mathrm{a}} \pm 9.0$ \\
Arginine & $85.1^{\mathrm{b}} \pm 4.6$ & $79.1^{\mathrm{ab}} \pm 2.9$ & $69.5^{\mathrm{a}} \pm 5.6$ \\
Histidine & $82.9^{\mathrm{b}} \pm 5.3$ & $75.5^{\mathrm{ab}} \pm 2.2$ & $70.4^{\mathrm{a}} \pm 6.3$ \\
Isoleucine & $81.0^{\mathrm{b}} \pm 6.1$ & $74.0^{\mathrm{ab}} \pm 2.6$ & $65.0^{\mathrm{a}} \pm 6.6$ \\
Leucine & $81.4^{\mathrm{b}} \pm 5.6$ & $75.8^{\mathrm{ab}} \pm 2.3$ & $68.2^{\mathrm{a}} \pm 5.8$ \\
Valine & $78.4^{\mathrm{b}} \pm 6.7$ & $72.4^{\mathrm{ab}} \pm 2.6$ & $60.3^{\mathrm{a}} \pm 7.1$ \\
\hline
\end{tabular}

$\mathrm{HM}=$ Hermetia meal diet with basic AA supply; SM = Spirulina meal diet with basic AA supply; ${ }^{1}$ Mean \pm standard derivation, ${ }^{2}$ Outlier detected with Dean-Dixon-Test $(\alpha \leq 0.2)$, ${ }^{\text {ab }}$ Means with different superscript letters within lines are significantly different $(p \leq 0.05)$.

high individual variation. In the future, the apcD data need to be further discussed as related to both results of nutrient deposition and parameters of complex dietary protein quality evaluation.

\subsection{Microbiology}

At the end of the trial, four mixed chyme samples of 5 chickens per group were studied for the presence or counts of several microbes and parasites. For the treatments under study (control, HM and SM) Campylobacter, Salmonella, and Parasites were not detected. Total bacteria counts given in CFU were similar for all dietary treatments (Table 6). Accordingly, the results for Enterococci and lactic acid bacteria were also similar among treatment groups. A higher variation was observed for Enterobacteriaceae, namely for coliform bacteria and E. coli, but without practical importance. However, the count of Enterobacteriaceae was lower for Spirulina fed chickens, and higher in birds fed Hermetia meal as compared to the control diet (3.7\%). In addition, the relative count of $E$. coli was lower when birds were fed the SM diet. Clostridia counts tended to be higher in birds of the HM and SM diets. In the case of control birds only one sample yielded detectable clostridia species. Clostridia were found in chickens fed SM or HM diets in three of the four studied samples. However, it has to be pointed out that only trends were observed.

Results for the evaluated feed samples are not shown in Table 6. Salmonella, Campylobacter, E. coli and clostridia species were not detectable in all three feed materials. The content of total CFU ranged between $4.77 \times 10^{4}$ in the control diet to $2.09 \times 10^{5}$ in diet HM to $1.92 \times 10^{5} \mathrm{CFU} / \mathrm{g}$ in diet SM. Total Enterobacteriaceae counts were nearly identical in all diets, ranging between $1.09 \times 10^{4}$ and $1.20 \times$ $10^{4} \mathrm{CFU} / \mathrm{g}$ feed. Similar results were found for the count of lactic acid bacteria. 
Table 6. Diet dependent counts (CFU/g) of microbes in the intestinal digesta of growing chickens at the end of the study ${ }^{1}$.

\begin{tabular}{|c|c|c|c|c|c|c|}
\hline \multirow[t]{2}{*}{ Diet } & \multicolumn{2}{|l|}{ Control } & \multicolumn{2}{|l|}{ HM } & \multicolumn{2}{|l|}{ SM } \\
\hline & Means \pm SD & $\begin{array}{l}\text { Proportion of } \\
\text { total CFU }\end{array}$ & Means \pm SD & $\begin{array}{l}\text { Proportion of } \\
\text { total CFU }\end{array}$ & Means \pm SD & $\begin{array}{c}\text { Proportion of } \\
\text { total CFU }\end{array}$ \\
\hline Total CFU & $1.21 \mathrm{E}+07 \pm 8.67 \mathrm{E}+06$ & - & $1.27 \mathrm{E}+07 \pm 1.01 \mathrm{E}+06$ & - & $1.29 \mathrm{E}+07 \pm 1.24 \mathrm{E}+07$ & - \\
\hline Enterococci & $6.88 \mathrm{E}+06 \pm 4.44 \mathrm{E}+06$ & 56.86 & $6.51 \mathrm{E}+06 \pm 4.42 \mathrm{E}+06$ & 51.25 & $5.95 \mathrm{E}+06 \pm 4.00 \mathrm{E}+06$ & 46.12 \\
\hline Enterobacteriaceae & $4.45 \mathrm{E}+05 \pm 3.87 \mathrm{E}+05$ & 3.68 & $1.40 \mathrm{E}+06 \pm 1.79 \mathrm{E}+06$ & 11.02 & $2.12 \mathrm{E}+05 \pm 1.66 \mathrm{E}+05$ & 1.64 \\
\hline E.coli & $1.48 \mathrm{E}+06 \pm 1.81 \mathrm{E}+06$ & 12.23 & $1.82 \mathrm{E}+06 \pm 1.87 \mathrm{E}+06$ & 14.33 & $5.98 \mathrm{E}+05 \pm 8.96 \mathrm{E}+05$ & 4.64 \\
\hline Coliform bacteria & $2.23 \mathrm{E}+06 \pm 2.32 \mathrm{E}+06$ & 18.43 & $3.70 \mathrm{E}+06 \pm 6.60 \mathrm{E}+06$ & 29.13 & $2.20 \mathrm{E}+05 \pm 3.60 \mathrm{E}+05$ & 1.71 \\
\hline Lactic acid bacteria ${ }^{*}$ & $1.98 \mathrm{E}+07 \pm 3.05 \mathrm{E}+07$ & - & $3.29 \mathrm{E}+07 \pm 3.68 \mathrm{E}+07$ & - & $2.35 \mathrm{E}+07 \pm 2.29 \mathrm{E}+07$ & - \\
\hline Clostridia $^{*}$ & $2.15 \mathrm{E}+01 \pm 4.30 \mathrm{E}+00$ & - & $8.56 \mathrm{E}+03 \pm 1.68 \mathrm{E}+04$ & - & $1.65 \mathrm{E}+03 \pm 1.27 \mathrm{E}+03$ & - \\
\hline
\end{tabular}

$\mathrm{HM}=$ Hermetia meal diet with basic AA supply; SM = Spirulina meal diet with basic AA supply; ${ }^{1}$ Mean \pm standard deviation ${ }^{*}$ cultivated separately under anaerobic conditions and consequently not part of the total CFU.

\section{Discussion}

As already reported [27], both in HM and SM diets an extended AA supplementation according to the IAAR [28] yielded superior growth responses and feed efficiency data, partly exceeding the results of the control birds. This extension investigated the further effects of these diets on the final body composition. The highest CP content after 5 weeks of fattening was observed in birds fed the control diet, but did not significantly different from HM+ diet data. The Spirulina diet $\mathrm{SM}+$ yielded the lowest body $\mathrm{CP}$ content, which was significantly below levels for control birds. Accordingly, the final body fat content was the lowest in control birds. One explanation for this observation is the lower $\mathrm{AME}_{\mathrm{N}}$ concentration as calculated in the control diets both for the starter and grower period due to elevated dietary fat content in diets with alternative proteins. However, the aim of this study was not to compensate this energetic effect by lowering the content of soybean oil in the experimental diets. The direct substitution demonstrates which dietary effects can be expected when SBM is substituted by Hermetia or Spirulina meal at high inclusion rates. In Hermetia meal diets this effect is caused by the high fat content in the partly defatted larvae meal, but not aimed to be compensated by diet formulation. In consequence, the observed significant effect on body fat content was expected. However, there was no significant effect between diets on the calculated body energy content, but there was an observed tendency for birds fed the SM+ diet to yield higher body energy contents as compared to the control chickens.

The changes in body composition directly correspond to the derived nutrient deposition data. The superior CPD in birds fed the AA balanced Hermetia meal diet $(\mathrm{HM}+)$ was remarkable, but only numerical as compared to the control diet. In contrast, a significantly lower CPD was found in chickens fed the SM+ diet. As expected, the lowest deposition of CP, EE and CA was observed in birds fed the HM or SM diets. The basic AA supplementation, even though on par with control diet levels, impaired nutrient deposition significantly. This observation 
underlines the need for an extended level of AA supplementation with an increasing substitution of SBM as already reported based on zoo-technical results [27]. Austic et al. [50] came to the same conclusion that an optimized AA supplementation is necessary in diets with microalgae for growing chickens. Improved growth rates in the starter period $(1-10 \mathrm{~d})$ were also observed by Elwert et al. [51] when lysine and methionine were added.

In line with the already stated elevated dietary energy concentration, chickens fed with the $\mathrm{HM}+$ diet yielded the highest fat deposition data. Regarding the GED, significantly enhanced energy retention was observed in chickens fed either of the AA supplemented diets ( $\mathrm{HM}+$ or $\mathrm{SM}+)$. Both diets yielded superior GED as compared to the control diet. The results also indicate that the comfortable dietary energy supply was not a limiting factor for dietary protein utilization when the AA supply was extended.

The derived protein quality data clearly underline that the experimental diets including Hermetia or Spirulina meal as substitutes for SBM with a basic level of AA supplementation (equal to that of the control diet) achieve insufficient feed protein quality. From this point of view it has to be concluded that in general an elevated level of fortification by feed amino acids is a precondition for high inclusion rates of the alternative proteins under study. Currently, only the HM+ diet achieved a protein quality equal to the control diet. Similar results were reported based on N-balance studies with growing chickens [52]. Accordingly, observed protein quality parameters of the $\mathrm{SM}+$ diet were significantly below that of the HM+ Diet. This clearly indicates that the extent of AA supplementation according to the IAAR [28] in Spirulina based diets needs further examinations to achieve an elevated and more efficient protein utilization with microalgae based broiler diets. In addition, when NPU was not standardized the difference between diet $\mathrm{HM}+$ and $\mathrm{SM}+$ remained insignificant. This observation underlines the importance of the applied standardization procedure to achieve valid data for feed protein quality evaluation.

The reported apcD data can only be considered as preliminary due to the limited number of repetitions; in spite of this, some significant differences were observed. The SM diet yielded the lowest apcD of $\mathrm{CP}$ and selected AAs, with the exception of methionine. The HM diet achieved intermediate results for apcD of $\mathrm{CP}$ and the other AAs. The observed impaired apcD of the SM diet supports the conclusion that in particular the algae meal of Spirulina platensis is more poorly digestible than the insect meal or SBM. This observation also partly explains the depression in protein quality parameters and decreased CPD found with Spirulina based diets. However, it has to be pointed out again that only four birds per diet were examined for the $\mathrm{apcD}$ in the present study, and therefore relatively high standard deviations accompanied the results. That underlines the preliminary nature of these data. Based on an in vitro study with Spirulina platensis, Devi et al. [53] reported $70 \%$ to $85 \%$ protein digestibility following a pepsin and subsequently pancreatin incubation. In addition, fresh Spirulina was found to be 
more digestible than freeze-dried or a sun-dried algae meal as was used in the current study. To our present knowledge, further pertinent studies assessing the digestibility of micro algae in chicken diets are not available. However, the observed lower digestibility of Spirulina meal was unexpected because microalgae do not encompass cellulose in the cell wall. The cell wall consists of a thin, unstable murein shell (peptidoglycans) which is not acting as a barrier for proteolytic enzymes during digestion [54], but carbohydrates and fibers could affect the digestibility and also create gastro-intestinal disturbances, flatulence or fluid retention [55].

The apparent total tract digestibility both of partly defatted Hermetia meal and highly defatted Hermetia meal was reported by Schiavone et al. [56], but no significant effect on digestibility of $\mathrm{CP}$ and organic matter was observed. However, the reported digestibility was lower (62\%) then the apcD of CP for Hermetia meal in the current study. Also De Marco et al. [18] reported lower apcD for CP (51\%) and AAs like Ile, Lys, Met, and Val (45\%, 56\%, 42\%, 62\%), but different approaches were applied, making direct comparisons unreliable. Another factor potentially affecting the digestibility of insect meals is the chitin content exclusively present in the exoskeleton of insects [57]. Chitin is a linear polysaccharide chain of $\beta(1 \rightarrow 4)$ - linked N-acetyl-D-glucosamine units which can be found in the fiber fraction [13] [58]. Birds are able to produce a chitinase [59], but a limitation in chitin digestibility remains [60]. Investigations from Longvah et al. [61] have demonstrated that high chitin contents in diets (up to 45\%) impaired protein digestibility. Hermetia larvae chitin content was reported by Diener et al. [62] with 8.7\% in DM; Kroeckel et al. [63] reported 9.6\% in DM. However, considering the final chitin content of diets when substituting $50 \%$ of SBM with Hermetia meal, no major impact on $\mathrm{pcD}$ of $\mathrm{CP}$ can be expected. Nevertheless, there is also a lack of reliable information about the chitin content of insects according to invalid analytical procedures insufficiently taking the $\mathrm{N}$ fraction of chitin into account [64].

Finally, the investigated microbial parameters in digesta samples yielded no significant effects for the total bacteria counts between diets. However, the proportional number of Enterobacteriaceae and coliform bacteria in relation to the total CFU were numerically elevated in chickens fed the HM diet as compared to the control. In contrast, in chickens fed the SM diet proportional counts especially for coliform bacteria were lower than in the control group. In addition, numerical higher values for clostridia species were found in chickens fed the alternative protein sources, but no clostridia and no difference in total Enterobacteriaceae counts were found directly in the diets themselves. Moula et al. [65] studied caecal samples from 13 day old chickens with or without feeding insects, but significant effects resulting from feeding $0 \%$ or $8 \%$ defrosted Hermetia larvae were not observed. However, Rhodobactericeae and Bacillaceae were lowest in caeca when the chickens received the whole larvae. Accordingly, no effects on microbial parameters in caecal contents were observed (total CFU, Enterobacte- 
riaceae, total Coliforms, Clostridia, Lactobacillus spp. and Bacillus spp.) when defatted Hermetia larvae meal up to 15\% instead of SBM was incorporated [66]. In contrast to several reports about stimulated growth of lactic acid bacteria by Spirulina meal in humans [67] [68] [69], no significant effect on the count of lactic acid bacteria was observed in the current study. Further studies are required to evaluate the possible effects of alternative proteins on microbial parameters in gastrointestinal tract of growing chickens in more detail.

\section{Conclusion}

This study has demonstrated that alternative feed proteins from Hermetia illucens larvae and Spirulina platensis may serve as a valuable partial replacer for soybean meal in diets for meat type growing chickens. However, an elevated level of fortification with feed amino acids is the precondition for the successful substitution of $50 \%$ of SBM by the alternative proteins under study. A basic AA level of supplementation equal to that of the control diet significantly impaired both nutrient deposition and dietary protein quality. An extended level of AA supplementation, well adapted to the IAAR, yielded significantly improved nutrient deposition and protein quality parameters with both of the alternative proteins. However, diets with Hermetia meal provided superior responses on CP deposition and protein quality as compared to Spirulina based diets. The preliminary data about apparent precaecal protein digestibility are not a full explanation for the observed results, further research is highly recommended. In addition, no significant changes of gut microbiology parameters were observed. The current study gives support for the great potential of the tested alternative protein sources, namely for insect meal from Hermetia illucens in meat-type chicken diets.

\section{Acknowledgements}

This study was supported by the Lower Saxony Ministry of Science and Culture (ZN 3041).

\section{References}

[1] Alexandratos, N. and Bruinsma, J. (2012) World Agriculture towards 2030/2050: The 2012 Revision. ESA Working Paper No. 12-03, Agricultural Development Economics Division, Food and Agriculture Organization of the United Nations (FAO), Rome.

[2] FAO (2013) Edible Insects-Future Prospects for Food and Feed Security. FAO Forestry Paper No. 171, FAO, Rome.

[3] Osava, M. (1999) Soy Production Spreads, Threatens Amazon in Brazil. Inter Press Service.

http://www.ipsnews.net/1999/09/environment-brazil-soy-production-spreads-threa tens-amazon/

[4] Steinfeld, H., Gerber, P., Wassenaar, T., Castel, V., Rosales, M. and De Haan, C. (2006) Livestock's Long Shadow: Environmental Issues and Options. FAO, Rome. 
[5] Fearnside, P.M. (2001) Soybean Cultivation as a Threat to the Environment in Brazil. Environmental Conservation, 28, 23-38.

[6] Garcia, M.A. and Altieri, M.A. (2005) Transgenic Crops: Implications for Biodiversity and Sustainable Agriculture. Bulletin of Science, Technology \& Society, 25, 335-353. https://doi.org/10.1177/0270467605277293

[7] Foley, J.A., Ramankutty, N., Brauman, K.A., Cassidy, E.S., Gerber, J.S., Johnston, M., Mueller, N.D., O’Connell, C., Ray, D.K., West, P.C., Balzer, C., Bennett, E.M., Carpenter, S.R., Hill, J., Monfreda, C., Polasky, S., Rockström, J., Sheehan, J., Stebert, S., Tilman, D. and Zaks, P.M. (2011) Solutions for a Cultivated Planet. Nature, 478, 337-342. https://doi.org/10.1038/nature10452

[8] Radermacher, F.J. (2014) Die Ernährungssituation der Menschheit-Überlegungen zu einem brisanten Thema. In: VDLUFA Schriftenreihe, Vol. 69, Kongressband, Berlin, 18-27.

[9] Barrows, F.T., Bellis, D., Krogdahl, A., Ashild, S., Feffrey, T. and Hermann, E.M. (2008) Report of the Plant Products in Aquafeed Strategic Planning Workshop: An Integrated, Interdisciplinary Research Roadmap for Increasing Utilization of Plant Feedstuffs in Diets for Carnivorous Fish. Reviews in Fisheries Science, 16, 449-455. https://doi.org/10.1080/10641260802046734

[10] Ruviaro, C.F., Gianezini, M., Brandao, F.S., Winck, C.A. and Dewes, H. (2012) Life Cycle Assessment in Brazilian Agriculture Facing Worldwide Trends. Journal of Cleaner Production, 28, 9-24. https://doi.org/10.1016/j.jclepro.2011.10.015

[11] Gandhi, V.P. and Zhou, Z. (2014) Food Demand and the Food Security Challenge with Rapid Economic Growth in the Emerging Economies of India and China. Food Research International, 63, 108-124. https://doi.org/10.1016/j.foodres.2014.03.015

[12] Shockley, M. and Dossey, A.T. (2014) Insects for Human Consumption. In: Morales-Ramos, J.A., Guadalupe Rojas, M. and Shapiro-Ilan, D.I., Eds., Mass Production of Beneficial Organisms. Invertebrates and Entomopathogens, Academic Press, Cambridge, MA, 617-652. https://doi.org/10.1016/B978-0-12-391453-8.00018-2

[13] Finke, M.D. (2002) Complete Nutrient Composition of Commercially Raised Invertebrates Used as Food for Insectivores. Zoo Biology, 21, 269-285.

https://doi.org/10.1002/zoo.10031

[14] Finke, M.D. (2004) Nutrient Content of Insects-Organic Value Recovery Solution Studies. Encyclopedia of Entomology, Springer, Dordrecht, 147-233.

https://link.springer.com/referenceworkentry/10.1007\%2F0-306-48380-7_2920

[15] Finke, M.D. (2012) Complete Nutrient Content of Four Species of Feeder Insects. Zoo Biology, 32, 27-36. https://doi.org/10.1002/zoo.21012

[16] Van Huis, A., Dicke, M. and van Loon, J.J.A. (2015) Insects to Feed the World. Journal of Insects as Food and Feed, 1, 3-5. https://doi.org/10.3920/JIFF2015.x002

[17] Makkar, H.P.S., Tran, G., Heuzé, V. and Ankers, P. (2014) State-of-the-Art on Use of Insects as Animal Feed. Animal Feed Science and Technology, 197, 1-33. https://doi.org/10.1016/j.anifeedsci.2014.07.008

[18] De Marco, M., Sartínez, S., Hernandez, F., Madrid, J., Gai, F., Rotolo, L., Belforti, M., Bergero, D., Katz, H., Dabbou, S., Kovitvadhi, A., Zoccarato, I., Gasco, L. and Schiavone, A. (2015) Nutritional Value of Two Insect Larvae Meals (Tenebrio molitor and Hermetia illucens) for Broiler Chickens: Apparent Nutrient Digestibility, Apparent Ileal Amino Acid Digestibility and Apparent Metabolizable Energy. Animal Feed Science and Technology, 209, 211-218.

https://doi.org/10.1016/j.anifeedsci.2015.08.006 
[19] Oluokun, J.A. (2000) Upgrading the Nutritive Value of Full-Fat Soybeans Meal for Broiler Production with either Fishmeal or Black Soldier Fly Larvae Meal (Hermetialllucens). Nigerian Journal of Animal Science, 3, No. 2. https://www.ajol.info/index.php/tjas/article/view/49768

[20] Schiavone, A., De Marco, M., Rotolo, L., Belforti, M., Martinez Mirò, S., Madrid Sanchez, J., Hernandez Ruiperez, F., Bianchi, C., Sterpone, L., Malfatto, V., Katz, H., Zoccarato, I., Gai, F. and Gasco, L. (2014) Nutrient Digestibility of Hermetia illucens and Tenebrio molitor Meal in Broiler Chickens. Proceedings of the 1 st International Conference Insects to Feed the World, Wageningen, 14-17 May 2014, 73. http://hdl.handle.net/2318/158360

[21] Vantomme, P. (2015) Way Forward to Bring Insects in the Human Food Chain. Journal of Insects as Food and Feed, 1, 121-129. https://doi.org/10.3920/JIFF2014.0014

[22] Commission Regulation (EU) 2017/893 (2017) Official Journal of the European Union of 24 May 2017 Amending Annex I and IV to Regulation (EC) No 999/2001 of the European Parliament and of the Council and Annexes X, XIV and XV to Commission Regulation (EU) No 142/2011 as Regards the Provisions on Processed Animal Protein. L 138/92-L138/116.

[23] Ross, E. and Dominy, W. (1990) The Nutritional Value of Dehydrated, Blue-Green Algae (Spirulina platensis) for Poultry. Poultry Science, 69, 794-800. https://doi.org/10.3382/ps.0690794

[24] Gongnet, G.P., Niess, E., Rodehutscord, M. and Pfeffer, E. (2001) Algae-Meal (Spirulina platensis) from Lake Chad Replacing Soybean-Meal in Broiler Diets. Archiv für Geflügelkunde, 65, 265-268.

[25] Bellof, G. and Carrasco Alarcon, L.S. (2013) Effect of Spirulina platensis in Organic Broiler Production. Einsatz der Mikroalge Spirulina platensis in der ökologischen Broilermast. Archiv für Geflügelkunde, 77, 73-80.

[26] Evans, A.M., Smith, D.L. and Moritz, J.S. (2015) Effects of Algae Incorporation into Broiler Starter Diet Formulations on Nutrient Digestibility and 3 to $21 \mathrm{~d}$ Bird Performance. The Journal of Applied Poultry Research, 24, 206-214. https://doi.org/10.3382/japr/pfv027

[27] Velten, S., Neumann, C., Bleyer, M., Gruber-Dujardin, E., Hanuszewska, M., Przybylska-Gornowicz, B. and Liebert, F. (2018) Effects of 50 Percent Substitution of Soybean Meal by Alternative Proteins from Hermetia illucens and Spirulina platensis in Meat-Type Chicken Diets with Graded Amino Acid Supply. Open Journal of Animal Sciences, 8, 119-136. https://doi.org/10.4236/ojas.2018.82009

[28] Wecke, C. and Liebert, F. (2013) Improving the Reliability of Optimal In-Feed Amino Acid Ratios Based on Individual Amino Acid Efficiency Data from N Balance Studies in Growing Chicken. Animals, 3, 558-573. https://doi.org/10.3390/ani3030558

[29] WPSA (1984) The Prediction of Apparent Metabolizable Energy Values for Poultry in Compound Feeds. World's Poultry Science Journal, 40, 181-182.

[30] Naumann, C. and Bassler, R. (1976-2004) Methodenbuch: Die chemische Untersuchung von Futtermitteln. Band III. VDLUFA-Verlag, Darmstadt, Germany.

[31] Pastor, A. (2014) Studien zur Aminosäurenwirksamkeit beim Mastgeflügel unter spezifischer Betrachtung der verzweigtkettigen Aminosäuren. Ph.D. Dissertation, Tierernährungsphysiologie, Georg-August-Universität, Göttingen, Germany.

[32] Fuller, M.F. (2004) The Encyclopedia of Farm Animal Nutrition. Publishing CABI, 
UK. https://doi.org/10.1079/9780851993690.0000

[33] Liebert, F. (2017) Invited Review: Further Progress Is Needed in Procedures for the Biological Evaluation of Dietary Protein Quality in Pig and Poultry Feeds. Archives Animal Breeding, 60, 259-270. https://doi.org/10.5194/aab-60-259-2017

[34] Samadi and Liebert, F. (2007) Lysine Requirement of Fast Growing Chickens: Effects of Age, Sex, Level of Protein Deposition and Dietary Lysine Efficiency. The Journal of Poultry Science, 44, 63-72. https://doi.org/10.2141/jpsa.44.63

[35] Samadi and Liebert, F. (2007) Threonine Requirement of Slow-Growing Male Chickens Depends on Age and Dietary Efficiency of Threonine Utilization. Poultry Science, 86, 1140-1148. https://academic.oup.com/ps/article/86/6/1140/2962714

[36] Liebert, F. (2008) Modelling of Protein Metabolism Yields Amino Acid Requirements Dependent on Dietary Amino Acid Efficiency, Growth Response, Genotype and Age of Growing Chicken. Avian Biology Research, 1, 101-110. https://doi.org/10.3184/175815508X388074

[37] Liebert, F. (2015) Basics and Applications of an Exponential Nitrogen Utilization Model ("Goettingen Approach") for Assessing Amino Acid Requirements in Growing Pigs and Meat Type Chickens Based on Dietary Amino Acid Efficiency. In: Sakomura, N.K., Gous, R., Kyriazakis, I. and Hauschild, L., Eds., Nutritional Modelling for Pigs and Poultry, CABI Publishing, Wallingford, Oxfordshire, UK, 73-87. https://doi.org/10.1079/9781780644110.0073

[38] Samadi, Wecke, C., Pastor, A. and Liebert, F. (2017) Assessing Lysine Requirement of Growing Chicken by Direct Comparison between Supplementation Technique and "Goettingen Approach". Open Journal of Animal Science, 7, 56-69. https://doi.org/10.4236/ojas.2017.71006

[39] Gebhardt, G. (1966) Die Bewertung der Eiweißqualität von Nahrungs- und Futtermitteln mit Hilfe des N-Bilanzversuches. In: Hock, A., Ed., Vergleichende Ernährungslehre des Menschen und seiner Haustiere, Gustav Fischer Verlag, Jena, Germany, 323-348.

[40] Wecke, C., Pastor, A. and Liebert, F. (2016) Validation of the Lysine Requirement as Reference Amino Acid for Ideal In-Feed Amino Acid Ratios in Modern Fast Growing Meat-Type Chickens. Open Journal of Animal Science, 6, 185-194. https://doi.org/10.4236/ojas.2016.63024

[41] Block, R.J. and Mitchell, H.H. (1946) The Correlation of Amino Acid Composition of Proteins with Their Nutritive Value. Nutrition Abstracts \& Reviews, 16, 249-278.

[42] Thong, H.T. and Liebert, F. (2004) Potential for Protein Deposition and Threonine Requirement of Modern Genotype Barrows Fed Graded Levels of Protein with Threonine as Limiting Amino Acid. Journal of Animal Physiology and Animal Nutrition, 88, 196-203. https://doi.org/10.1111/j.1439-0396.2004.00457.x

[43] Wecke, C. and Liebert, F. (2009) Lysine Requirement Studies in Modern Genotype Barrows Dependent on Age, Protein Deposition and Dietary Lysine Efficiency. Journal of Animal Physiology and Animal Nutrition, 93, 295-304. https://doi.org/10.1111/j.1439-0396.2009.00923.x

[44] Farke, J. (2011) Studien zur Aminosäurenwirksamkeit beim Mastgeflügel unter spezifischer Betrachtung der schwefelhaltigen Aminosäuren. Ph.D. Dissertation, Tierernährungsphysiologie, Georg-August-Universität, Göttingen, Germany.

[45] Pastor, A., Wecke, C. and Liebert, F. (2013) Assessing the Age-Dependent Optimal Dietary Branched-Chain Amino Acid Ratio in Growing Chicken by Application of a Nonlinear Modeling Procedure. Poultry Science, 92, 3184-3195.

https://doi.org/10.3382/ps.2013-03340 
[46] Kluth, H., Mehlhorn, K. and Rodehutscord, M. (2005) Studies on the Intestine Section to Be Sampled in Broiler Studies on Precaecal Amino Acid Digestibility. Archives of Animal Nutrition, 59, 271-279. https://doi.org/10.1080/17450390500217058

[47] Brandt, M. and Allam, S.M. (1987) Analytik von $\mathrm{TiO}_{2}$ im Darminhalt und Kot nach Kjeldahlaufschluss. Archives of Animal Nutrition, 37, 453-454.

[48] Kluth, H. and Rodehutscord, M. (2006) Comparison of Amino Acid Digestibility in Broiler Chickens, Turkeys and Pekin Ducks. Poultry Science, 85, 1953-1960.

[49] Dryden, M.W., Payne, P.A., Ridley, R. and Smith, V. (2005) Comparison of Common Fecal Flotation Techniques for the Recovery of Parasite Eggs and Oocysts. Veterinary Therapeutics, 6, 15-28.

[50] Austic, R.E., Mustafa, A., Jung, B., Gatrell, S. and Lei, X.G. (2013) Potential and Limitation of a New Defatted Diatom Microalgal Biomass in Replacing Soybean Meal and Corn in Diets for Broiler Chickens. Journal of Agricultural and Food Chemistry, 61, 7341-7348. https://doi.org/10.1021/jf401957z

[51] Elwert, C., Knips, I. and Katz, H. (2010) A Novel Protein Source: Maggot Meal of the Black Soldier Fly (Hermetia illucens) in Broiler Feed. In: Gierus, M., Kluth, H., Bulang, M. and Kluge, H., Eds., Tagung Schweine und Geflügelernährung, Institut für Agrar- und Ernährungswissenschaften, Universität Halle Wittenberg, Lutherstadt Wittenberg, Germany, 140-142.

[52] Neumann, C., Velten, S. and Liebert, F. (2018) Improving the Dietary Protein Quality by Amino Acid Fortification with a High Inclusion Level of Micro Algae (Spirulina platensis) or Insect Meal (Hermetia illucens) in Meat Type Chicken Diets. Open Journal of Animal Sciences, 8, 12-26. https://doi.org/10.4236/ojas.2018.81002

[53] Devi, M.A., Subbulakshmi, G., Devi, K.M. and Venkataraman, L.V. (1981) Studies on the Proteins of Mass-Cultivated, Blue-Green Alga (Spirulina platensis). Journal of Agricultural and Food Chemistry, 29, 522-525. https://doi.org/10.1021/jf00105a022

[54] Grewe, C.B. and Pulz, O. (2012) The Biotechnology of Cyanobacteria. In: Whitton, B.A., Ed., Ecology of Cyanobacteria II: Their Diversity in Space and Time, Springer, Dordrecht, 707-739. https://doi.org/10.1007/978-94-007-3855-3_26

[55] Becker, E.W. (2004) Microalgae in Human and Animal Nutrition. In: Richmond, A., Ed., Handbook of Microalgal Culture: Biotechnology and Applied Phycology, Blackwell Science, Oxford, 312-351.

[56] Schiavone, A., De Marco, M., Martinez, S., Dabbou, S., Renna, M., Madrid, J., Hernandez, F., Rotolo, L., Costa, P., Gai, F. and Gasso, L. (2017) Nutritional Value of a Partially Defatted and a Highly Defatted Black Soldier Fly Larvae (Hermetia illucens L.)Meal for Broiler Chickens: Apparent Nutrient Digestibility, Apparent Metabolizable Energy and Apparent Ileal Amino Acid Digestibility. Journal of Animal Science and Biotechnology, 8, 51. https://doi.org/10.1186/s40104-017-0181-5

[57] Hudson, S.M. and Jenkins, D.W. (2001) Chitin and Chitosan. Encyclopedia of Polymer Science and Technology, 1, 569-580.

https://doi.org/10.1002/0471440264.pst052

[58] Lindsay, G.J.H., Walton, M.J., Adron, J.W., Fletcher, T.C., Cho, C.Y. and Cowey, C.B. (1984) The Growth of Rainbow Trout (Salmo gairdneri) Given Diets Containing Chitin and Its Relationship to Chitinolytic Enzymes and Chitin Digestibility. Aquaculture, 37, 315-334. https://doi.org/10.1016/0044-8486(84)90297-7

[59] Suzuki, M., Fujimoto, W., Goto, M., Morimatsu, M., Syuto, B. and Toshihiko, I. (2002) Cellular Expression of Gut Chitinase mRNA in the Gastrointestinal Tract of Mice and Chickens. Journal of Histochemistry \& Cytochemystry, 50, 1081-1098. 
https://doi.org/10.1177/002215540205000810

[60] Hossain, S.M. and Blair, R. (2007) Chitin Utilization by Broilers and Its Effect on Body Composition and Blood Metabolites. British Poultry Science, 48, 33-38. https://doi.org/10.1080/00071660601156529

[61] Longvah, T., Mangthya, K. and Ramulu, P. (2011) Nutrient Composition and Protein Quality Evalution of Eri Silkworm (Samia ricinii) Prepupae and Pupae. Food Chemistry, 128, 400-403. https://doi.org/10.1016/j.foodchem.2011.03.041

[62] Diener, S., Zurbrügg, C. and Tockner, K. (2009) Conversion of Organic Material by Black Soldier Fly Larvae: Establishing Optimal Feeding Rates. Waste Management \& Research, 27, 603-610. https://doi.org/10.1177/0734242X09103838

[63] Kroeckel, S., Harjes, A.G.E., Roth, I., Katz, H., Wuertz, S., Susenbeth, A. and Schulz, C. (2012) When a Turbot Catches a Fly: Evaluation of a Prepupae Meal of the Black Soldier Fly (Hermetia illucens) as Fish Meal Substitute-Growth Performance and Chitin Degradation in Juvenile Turbot (Psetta maxima). Aquaculture, 364-365, 345-352. https://doi.org/10.1016/j.aquaculture.2012.08.041

[64] Hahn, T., Roth, A., Febel, E., Fijalowska, M., Schmitt, E., Arsiwalla, T. and Zibek, S. (2018) New Methods for High Accuracy Insect Chitin Measurement. Journal of the Science of Food and Agriculture. https://onlinelibrary.wiley.com/doi/abs/10.1002/jsfa.9044

[65] Moula, N., Hornick, J.-L., Cabaraux, J.-F., Korsak, N., Daube, G., Dawans, E., Antoine, N., Taminiau, B. and Detilleux, J. (2017) Effects of Dietary Black Soldier Fly Larvae on Performance of Broilers Mediated or Not through Changes in Microbiota. Journal of Insects as Food and Feed, 4, 31-42. https://doi.org/10.3920/JIFF2017.0011

[66] Cullere, M., Tasoniero, G., Giaccone, V., Miotti-Scapin, R., Claeys, E., De Smet, S. and DalleZotte, A. (2016) Black Soldier Fly as a Dietary Protein Source for Broiler Quails: Apparent Digestibility, Excreta Microbial Load, Feed Choice, Performance, Carcass and Meat Traits. Animal, 10, 1923-1930. https://doi.org/10.1017/S1751731116001270

[67] Bhowmik, D., Dubey, J. and Mehra, S. (2009) Probiotic Efficiency of Spirulina platensis-Stimulating Growth of Lactic Acid Bacteria. World Journal of Dairy \& Food Sciences, 4, 160-163.

[68] Sánchez, M., Bernal-Castillo, J., Rozo, C. and Rodríguez, I. (2003) Spirulina (Arthrosphira): An Edible Microorganism: A Review. Universitas Scientarium, 8, 7-24.

[69] Paradaa, J.L., Zulpha de Caire, G., Zarraco de Mule, M.C. and Storni de Cano, M.M. (1998) Lactic Acid Bacteria Growth Promoters from Spirulina platensis. International Journal of Food Microbiology, 45, 222-228.

https://doi.org/10.1016/S0168-1605(98)00151-2 